\title{
Charles Tilly, globalization, and labor's citizen rights
}

\author{
ANTONINA GENTILE ${ }^{1, a}$ AND SIDNEY TARROW ${ }^{2 *}$ \\ ${ }^{1}$ Department of Political Science, Johns Hopkins University, Baltimore, MD, USA \\ ${ }^{2}$ Department of Government, Cornell University, Ithaca, NY, USA
}

Since the 1990s, observers have seen globalization impairing labor's rights. We take Charles Tilly as an exemplar of this view, subjecting his 1995 article to critical appreciation. We argue that Tilly, known for his work on the National Social Movement, overlooked the fact that some unions under pressure from global neo-liberalism can employ a protest repertoire employing their citizen rights, while others continue to use labor rights. We use port workers, who are directly exposed to globalization, to show how different political opportunity structures and different strategic choices influence these choices. In Sweden, our exemplar of a neo-corporatist system, we find that the employment of labor rights continues to be robust; in the USA, our exemplar of a fully-fledged neo-liberal system, we find much greater recourse to a repertoire calling on citizen rights. Finally, in Australia and Great Britain, countries undergoing a shift to neo-liberalism in the 1980s and 1990s, we show that strategic choice influences how effectively unions adapt to shifts towards neo-liberalism: Australian unions effectively used citizen rights while the British port unions failed to make this strategic shift.

Keywords: citizen rights; dock workers; globalization; labor; labor rights; protest repertoire

\section{Introduction}

In 1974, Edward Shorter and Charles Tilly published their landmark study, Strikes in France, 1830-1968 (Shorter and Tilly, 1974). In it, they forged the argument that the strike was 'an instrument of working-class political action' intended to impress 'the political authorities of the land, in the form of either the government itself or powerful members of the polity' (1974: 343). In contrast to the dominant industrial relations literature - which regarded the strike as a strictly industrial action - Shorter and Tilly were putting together capital, contention, and states.

This was not the last time the late Charles Tilly would combine capital, contention, and states. Throughout his long and distinguished career, he saw the state as the framework within which contention - even contention aimed at private actors - was shaped. And for Tilly, states were never simply mechanisms for

\footnotetext{
a Antonina Gentile is completing her PhD in Political Science at the John Hopkins University. Sidney Tarrow teaches political science and sociology at Cornell University.

* E-mails: antonina.gentile@jhu.edu, sgt2@cornell.edu
} 
control of internal coercion, control, and commitment: they were part of the state system, one in which rulers' actions within their bailiwicks was shaped by what happened outside their control (Tilly, 1990).

The same was true of organized labor. Consider, for example, what the French labor movement learned from labor movements elsewhere, and how it responded to the variations in the international political economy. The enduring ritual of le premier mai was a direct diffusion of the American 8-hour Day Movement (Tartakowsky, 2005). The great strike wave of 1933-35 was a direct response to the international depression of those years (Tilly, 1986: 326-327). And the great political strikes of the years 1946-47 were in the vanguard of the international cold war that would freeze the map of Europe into two competing parts for the next four decades. Yet Strikes in France left the international class struggle in the background.

By the end of the 1970s, Tilly broadened the links he drew between labor contention and national politics into a 'polity model' (Tilly, 1978), which focused attention on the political processes that constitute and reconstitute a polity. But it was only in another co-authored book, Work Under Capitalism, with Chris Tilly (Tilly and Tilly, 1998), that he returned to the theme of working class contention. But even there, the focus is mainly on the intra-national level, and the words 'international' and 'globalization' do not even appear in the index.

But as globalization advanced in the 1990s, Tilly was too acute an observer of the impact of social change to fail to notice that this process was threatening labor's rights. In an important article in 1995, he would argue that globalization threatens labor's rights because it erodes the powers of the national state. ${ }^{1}$ He concluded: 'If workers are to enjoy collective rights in the new world order, they will have to invent new strategies at the scale of international capital' (Tilly, 1995b: 5). 'To the extent that states dissolve, so does citizenship and thereby democracy' (1995b: 22).

The decline of labor movements in the 1990s and into the new century has underscored the prescience of Tilly's 1995 article, and the 2008 crisis has demonstrated dramatically how closely knit the new global economy has become. But there were three lacunae in that article:

- First, most of Tilly's claims related to labor rights and not to the citizen rights that labor and other social groups won to various degrees.

- Second, Tilly's article elided the differences in capitalist regimes, and their government responses to (and even authorship of) globalization's threats to their labor movements.

- Third, Tilly never made clear how the choices of labor organizers can either lead to labor's collapse or help labor to adapt to the changes afoot, nor what might

\footnotetext{
1 'Globalization Threatens Labor's Rights' was published with responses from prominent labor scholars such as Immanuel Wallerstein, Aristide Zolberg, and Lourdes Beneria, and it later helped Arrighi and Silver order the literature's emerging arguments in their path-braking long-view studies of globalization (Arrighi and Silver, 1999; Silver, 2003).
} 
predispose union leaderships to make more appropriate choices. We base our analysis below on this critical difference.

We use a Tillian theoretical innovation - the repertoire of contention - to modify his substantive conclusions about globalization and labor's rights (Tilly, 2008).

\section{Labor rights and citizen rights}

Although organized labor's primary mode of mobilization is at the workplace, supplemented, in some regime types, by unions' association with political parties, labor movements have had long experience utilizing members' rights as citizens. In fact, if we return to the 19th century origins of today's labor movements, we will recall that much of their efforts were mobilized on behalf of citizen rights especially the suffrage, which was successfully conquered for most male workers between 1884 in Britain and 1920 in Sweden (Rokkan, 1970: 84-85). Although citizen rights are often labeled 'bourgeois rights', labor is no stranger to them. Moreover, labor has often combined citizen rights to supplement its labor rights claims in specifically labor campaigns.

\section{Regime type and labor claims-making}

Tilly was fundamentally a comparative historical sociologist, and often explicitly compared contention in different regimes (Tilly, 2006). Yet there is little hint in 'Globalization threatens labor's rights' of how different capitalist regimes both respond to globalization and structure their labor movements' strategies, when faced with threats to their rights. We believe, and will try to show in the ports sector - how different capitalist regimes structure the ways in which organized labor uses different combinations of labor and citizen rights in its defense against the threat of globalization. We will also show that even in similarly neo-liberalizing states, labor's choice to either remain with traditional repertoires of contention or adapt to the new regime can make a big difference in its capacity to adapt.

In this article, we are less concerned with predicting how effectively domestic organized labor will be able to mobilize transnationally than with how transnational mobilizations in the face of globalization intersect with the major forms of capitalist regime. We will argue that differences in regime type continue to structure repertoires of contention and that - even when faced with globalization's threats - workers respond in terms of the particular opportunity structures of the regimes in which they live and work, in order to enable the withdrawal of their labor power for either their own immediate defense or to engage in international solidarity with other workers (Tarrow, 2005; Gentile, 2009).

Broadly speaking, corporatist capitalist states largely use a labor repertoire afforded them by the categorical power of their labor rights domain; by contrast, in neo-liberal capitalist states, where organized labor holds little categorical power, labor movements largely rely on a repertoire enabled by the one main 
rights domain - that is, citizen rights - left available to them in this form of state which most approximates the ideal of pro-neo-liberal globalization discourse. We operationalize a citizen repertoire and distinguish it from a labor repertoire by organized labor's heavy reliance on performances pertaining to the social movement campaign repertoire in order to enable its action: for example, demonstrations, rallies, and court room occupations, and the direct involvement of non-union community members for enabling a strike action. By contrast, we operationalize the labor repertoire as a more direct withdrawal of labor power, using primarily performances such as the strike - from the selective strike to a full blockade, the go-slow, work-to-rule, and so on.

We begin by returning to Tilly's landmark article. We then turn to how union movements in two different countries representing two different regimes of capitalism - the USA and Sweden - responded to the same transnational labor campaign. We continue by showing how differently Australian and British national unions responded to their respective regime shifts from corporatist to a neo-liberal regime, with very different results for labor's capacity to adapt to neoliberal globalization.

\section{Tilly, globalization, and labor's rights}

Tilly defined 'globalization' as 'an increase in the geographic range of locally consequential social interactions, especially when that increase stretches a significant proportion of all interactions across international or intercontinental limits' (Tilly, 1995b: 1-2). His primary concern, however, was its impact on labor. With the rise of international capital and supranational bodies that strongly reflect the interest of capital - the International Monetary Fund; the World Bank; the North American Free Trade Agreement, which had just been approved when he wrote; and the World Trade Organization (WTO) - the immediate loser under globalization, Tilly held, was the state. This boded ill for workers engaged in conflicts with their class antagonists; for the development of labor movements over the past 150 years had been intimately related to the development of the national state in which they had become embedded. Without the state's enforcement of rights, and without the state as a site structuring political contention, labor seemed doomed to weakening. Tilly also makes a more explicit assertion, namely that ' $[\mathrm{t}] \mathrm{o}$ the extent that states dissolve, so does citizenship and thereby democracy' (Tilly, 1995b: 22).

To students of Tilly's work, his apparent readiness to relinquish the state tout court went against the grain of his long-standing commitment to the idea that repertoires of contention are shaped and structured by the national state (Tilly, 1978, 1995a, 2006). Tilly did suggest in his article that workers would need 'to invent new strategies at the scale of international capital' (1995b: 5), and that, in a globalized world, the potential future guarantors of worker rights would need to be international agencies or consortia of states. But with an uncharacteristic 
pessimism about peoples' ability to resist and influence large-scale processes, he cast an eye around the world of 1995 to find that such new strategies were not emerging. Instead, he observed that labor appeared to be turning to protectionism, rather than to international solidarity.

A lot has happened in transnational politics since 1995. But much of it supports Tilly's fear of globalization threatening labor's rights. In the USA, the mobilization of the labor movement against the Seattle WTO Ministerial in 1999 quickly subsided and was at heart protectionist and, after 9/11, organized labor defected from its short-lived participation in global justice coalitions (Hadden and Tarrow, 2007). In Western Europe, despite the presence of the European Trade Union Confederation (ETUC) at the heart of the European Union (EU), there has been limited evidence of labor's capacity to mobilize across borders. On the global scene, the International Confederation of Free Trade Unions (ICFTU) has been unable to construct an international consensus and sustained campaign on fair labor standards.

But the decade since Seattle causes us to moderate Tilly's fear that the state was eroding in the face of globalization and its institutional avatars. Consider these examples:

- In Latin America and elsewhere, the so-called 'Washington Consensus' that appeared to be eroding labor rights in the 1990s was cracked by the election of a wave of new anti-neo-liberal governments (Cleary, 2006). Although much was made of the 'race to the bottom' in the late 1990s, Latin Americanists have shown that institutional channels exist to protect labor's rights (Compa, 2001; Kay, 2005; Murillo and Schrank, 2005).

- In Belgium, the closure of Renault's Vilvoorde plant demonstrated that in specific instances, organized labor can mobilize across borders and even gain the support of the media and of national political elites (Lagneau and Lefébure, 2001).

- In Europe, in general, elements of organized labor have played an important part in the unemployed workers' marches (Balme et al., 2001) and in the Global and European Social Forums (Della Porta, 2007), and even the ETUC has begun to come out of its protective shell to participate in transnational campaigns against EU directives (Erne, 2008; Parks, 2008: Ch. 6).

- In South Africa, the powerful labor movement, the Congress of South African Trade Unions (COSATU), took effective action to block the unloading of a shipload of Chinese weapons destined for Zimbabwe and has been pressuring the African National Congress government to reduce its support for the Mugabe regime.

- And crossing the Atlantic, large British and American unions recently announced the formation of 'Workers Uniting', which will represent more than 2.8 million workers in the steel, paper, oil, health care, and transportation industries (New York Times, 3 July 2008: 3).

It is too soon to tell but there may well be a transnational Polanyian countermovement in progress against the assaults of globalization (Caporaso and Tarrow, 2009). 


\section{Regime types and responses to neo-liberal globalization}

But what form will this countermovement take, to the extent that we can observe it, and how will it dovetail with the varieties of capitalist regimes in the world today? We suggest, building on the work of political economists Esping-Andersen (1996), Crouch and Streeck (1997, 2006), Hall and Soskice (2001), Pontusson (2005), Traxler (1995), Huber and Stephens (2001), and Frege and Kelly (2004), that neo-liberal transformations have not been sweeping or uniform, and, further, that they have been refracted by historical legacies of rights domains and contemporary domestic struggles. Moreover, we note the recent strengthening of organized labor's categorical power in some southern European states through new political exchange processes (Pizzorno, 1978) that had long been deemed a difficult if not impossible development there, but where instead new pacts between union movements, employers, and governments have been established to foster greater national competitiveness (Regalia and Regini, 1997; Ferner and Hyman, 1998; Regini, 2000, 2003; Rhodes, 2001, 2003; Baccaro, 2002; Regalia, 2003).

In short, many capitalist regimes, though changing in response to globalization, have been loathe to see workers' labor rights abridged, while some in southern Europe have even moved towards a stronger categorization of labor. By contrast, radically neo-liberalizing government elites - such as those in Great Britain since the Prime Ministership of Margaret Thatcher and Australia since that of John Howard began - have worked hard to foster regime change from a corporatist to a neo-liberal regime of capitalism, and have done so by politically and institutionally decategorizing organized labor and its historically built labor rights domain from the capitalist state.

What does this have to do with globalization? Only this: that in responding to the threats of globalization, labor movements can choose among a panoply of forms of contention, drawing on the domain of rights - whether citizen or labor rights - that offers them greater opportunity. Moreover, contrary to the expectations of the 'Race to the Bottom' thesis that Tilly specified in 'Globalization threatens labor's rights', our research shows that it is precisely in radically neo-liberalizing regimes that recent campaigns demonstrate organized labor's capacity to draw upon that most domestically embedded of rights domains citizen rights - to survive the onslaught.

Let us first put this in the most general historical terms. When organized labor unions first began to mobilize at a national scale in the 19th century, organizers sought two kinds of rights and forms of categorical recognition: strictly labor rights, such as the right to organize, to engage in state-regulated collective bargaining, to seniority and various welfare arrangements which encompassed T.H. Marshall's 'social rights' (Marshall, 1950); and citizen rights, most of which labor shared with other classes and which encompass Marshall's 'civil' and 'political' rights. These areas of rights - labor rights and citizen rights - constituted institutionally distinct domains of domestically rooted rights. 
Workers' citizen rights - or at least alliances with citizens from other classes have not been ignored. In the burgeoning literature on 'social movement unionism', community embeddedness and alliances with non-labor organizations and movements have taken center stage in explaining union revitalization. For example, in North America the 'Justice for Janitors' campaign by the Service Employees International Union, similar campaigns by the Hotel and Restaurant Employees International Union, and the victory of the Sweeney ticket in national union elections have all been seen as markers of the growth of social movement unionism (Johnston, 1994; Seidman, 1994; Moody, 1997, 1998; Dreiling and Robinson, 1998; Waterman, 1998; Dreiling, 2001; Turner et al., 2001; Milkman and Voss, 2004). This cluster of strategic innovations includes: unions' sustenance by local communities; the adoption of progressive political agendas ranging from community child care to anti-war mobilization; and a propensity to form coalitions with social movements committed to such agendas.

But the use of citizen rights goes beyond the progressive thrust of social movement unionism and its universalizing expectations. In the USA, unions as ideologically disparate as the West Coast's International Longshore and Warehouse Union (ILWU) and the conservative East Coast's International Longshoremans' Association (Kimeldorf, 1988) rely heavily on citizen rights and alliances with citizens in order to conduct their actions. Yet reliance on citizen rights is not universal. In Sweden, neither the Social Democratic Transport Union nor the Anarcho-Syndicalist Dockers' Union utilizes citizen rights and alliances to engage in action. Instead, they rely entirely on their labor rights. And in Australia, we found a shift of strategies employing, successively, labor and citizen rights strategies.

How can we explain this difference? Although both labor and citizen rights are available in all OECD regimes, we argue that the density of labor's political and institutional categorization varies significantly by capitalist regime type: ${ }^{2}$

- Neo-liberal regimes greatly restrict labor rights both politically and institutionally; consequently, unions in such regimes tend to rely heavily on their citizen rights and on alliances with other citizens to defend their interests and engage in international labor solidarity;

\footnotetext{
${ }^{2}$ Our typology of regimes of capitalism is similar to that of the Varieties of Capitalism School, but not identical. This difference is because it was developed using labor-focused variables rather than capitalfocused variables: for example, 'bargaining coverage' which captures 'labor-related institutional density', and 'political exchange' processes, as conceived by Pizzorno (1978) in his classic book during the 1970s corporatism debate. As such, the typology resembles more the typology and classification of states by scholars of the welfare state, which aptly focus on social rights and noted the peculiar strength and organizational capacity of labor in Antipodean states (Castles, 1993, 2004; Esping-Andersen, 1999; Huber and Stephens, 2001). Our regimes of capitalism are broadly two - the neo-liberal and the corporatist-capitalist regime - though, for purposes not directly related to this paper, we also distinguish four sub-clusters of corporatist regimes: the Social Partnership (e.g. Germany), the Social Democratic (e.g. Sweden), the Antipodean (Australia until 1997 and New Zealand until 1990), and the New Corporatist (e.g. Italy). For details, see Gentile (2009).
} 
- Corporatist regimes strongly categorize labor rights politically and institutionally; consequently unions in such regimes rely on their labor rights and on alliances with other unions to defend their rights and engage in international labor solidarity;

- Unions in countries in transition from a corporatist to a neo-liberal regime tend to demonstrate a shift from strictly labor rights to the employment of citizen rights.

By tracing the repertoires, categories, and rights domains utilized by organized labor in different types of capitalist regimes, we can show how organized labor utilizes domestic opportunity structures according to their comparative categorical power in different types of capitalist regimes. We choose the conflicts of port workers against their employers for comparison, first because port work is on the cutting edge of the domestic and international markets, and hence is highly exposed to the threats of globalization. If Tilly's 1995 argument were to hold, we would expect to see port worker unions utilizing similar repertoires and rights domains across different regimes during the same campaign; and we would not expect to see a shift in a port union's repertoire and prominently used rights domain when a regime changes from a corporatist to a neo-liberal regime. Second, as uniformly strong unions across a universe of OECD organized workers, port worker unions are also among the first to be targeted by neo-liberalizing governments and interested elites of capital intent on regime change. Thus, as vanguard unions, their successes and failures are instructive of the strategic choices that best and least serve labor, while detailed ethnographic investigation can help us trace the process through which those choices are made.

\section{Dock workers' transnational campaigns}

Across the globe, port workers have suffered greatly from the impact of the internationalization of ship line ownership, the growth of 'global port operators', and greater concentration of port service ownership (Dombois and Heseler, 2000). But because they are connected through the ships they service to port workers in other countries and increasingly the same port operators, they have considerable incentive to mobilize transnationally. Yet, even these most globally linked workers, we will show, are directly embedded in the political opportunity structures of states in different capitalist regimes. As a result, when faced by a common transnational campaign, they respond by using different repertoires. And when a state undergoes regime change, port workers' change their repertoire to increase their likelihood of success in the new regime. Moreover, the repertoire that best serves labor in a neo-liberal as opposed to a corporatist regime is drawn from that most state-defining of rights domains: the citizen domain.

The episodes we will use to demonstrate these variations are, first, the response of port workers on the USA's West and East Coasts, and in Sweden to the 
transnational campaign triggered by the Liverpool Dockers' efforts to gain their reinstatement. In these two countries, representing two different capitalist regimes - the neo-liberal and the corporatist - we will see two different repertoires used for the same campaign. ${ }^{3}$ Second, we will test the hypothesis that links repertoires to regimes on a separate campaign, the Maritime Union of Australia (MUA)-Patrick dispute in Australia. But we will also show that labor unions are not simply the slaves of political opportunities; opportunities must be perceived and seized in order to guide union strategy to success.

We begin with the local campaign of the Liverpool Dockers who triggered a transnational mobilization of dockers ${ }^{4}$ around the world.

\section{The Liverpool Dockers' campaign for reinstatement}

When, in 1995, 500 Liverpool Dockers employed by the Mersey Docks and Harbour Co. (MDHC) refused to cross a picket line by dismissed Torside workers, they met the wrath of the Thatcher government's labor de-categorizing revolution. Now an illegal practice, their 'secondary boycott' brought about their mass dismissal and threatened their union, the Transport and General Workers Union (TGWU), with bankruptcy if it were to declare its official support for the Dockers' action. That total closure to opportunity spurred the Dockers, their wives, and supporters to organize a transnational campaign to, on one hand, pressure the MDHC along its trade routes, and, on the other, push their union to find solutions to the post-Thatcher constraints it found itself with and to muster concerted domestic and international support for the Dockers' full reinstatement.

By various mechanisms, the Liverpool Dockers constructed a transnational network of dockers and organized two historic international days of action: They toured ports with direct trading links to Liverpool to publicly appeal to their counterparts, with whose support they, at times, engaged in direct action against Liverpool-bound ships; they organized conferences of port workers around the world to take stock of their common grievances and make common cause of the Liverpool dispute; they reactivated networks of European Dockers from struggles they had long ago been involved in and they drew on their solidarity credit from

\footnotetext{
3 We further note that the episodes of solidarity with Liverpool that have been selected are drawn from a pool of episodes that are independent of the Liverpool Dockers' First International Day of Action in January 1997, which was supported by the International Transport Workers Federation. This controls against possible 'labor INGO effect' on the actions used.

${ }^{4}$ Port workers have national-culturally specific nouns. Britain normally refers to them as 'dockers', the USA and Canada as 'longshore workers' or 'longshoremen', and Australia as 'wharfies'. Away from the English-speaking world, there are also differences, including differences among port workers themselves, for example, in Italy between 'portuali' (those with primarily a craft unionism identity based on the former port-level syndicalist structure, the Compagnia Portuale) and 'lavoratori portuale' (those with a more recently developed industrial union identity following the post 1990s port reforms that privatized the former Compagnie and created multiple employers in each port).
} 
those struggles; they elicited the brokerage of sympathetic political activists in countries where they could not initially reach the pertinent union and they further elicited the brokerage of sympathetic unions in the International Transport Workers Federation (ITF), which had been restrained by the TGWU from organizing an international campaign; they signalled their (Irish) cultural affinity to a conservative New York union leadership that was not normally disposed to international solidarity activities; and, through secondary networking, they dispatched 'Women of the Waterfront' to Open World and other conferences to rally support for their cause in non-labor circles.

There were commonalities in the responses of port workers around the world to the mobilization launched by the Liverpool Dockers - letters of support, donations, and resolutions. But in responding to this call for solidarity, the different political opportunity structures of different groups of workers deeply influenced the repertoires of contention they employed. In neo-liberal USA, West and East Coast port workers responded to the conflict by relying on their civil rights under the US Constitution and on related state legislation, while in corporatist Sweden, Gothenborg's Dockers utilized their legal right to conduct on-going solidarity boycotts of the Liverpool-loaded Atlantic Container Line (ACL). With both countries each featuring two unions with disparate ideologies, we will also show that the repertoires were regime-based, regardless of union ideology.

\section{Using citizen rights on the American West Coast}

In September 1997, Oakland port union activists from the ILWU ${ }^{5}$ noted the pending arrival of a ship from Thamesport. Since their meetings with the Liverpool Dockers at the Liverpool conferences and the Dockers' tour of the USA, the activists had been on the look out for ships from Liverpool, only to find that the West Coast of the USA had no direct trade link to it. But when the activists asked the Dockers and their internet-operating supporters about the Neptune Jade, their search was over: MDHC had newly developing interests in Thamesport, making the ship a 'legitimate target' for displays of solidarity. As militants and members of many social and political groups, Oakland's ILWU activists mobilized their networks for a picket to meet the ship at port. Those ILWU unionists who participated in the picket were not on duty at the time; while those who were, focused on the one legal provision that (indirectly) allowed them scope for supporting a blockade: their health and safety rights.

The community picket, together with the unionized workers' refusal to cross it, succeeded in keeping the Neptune Jade off the coast for days. When the ship ventured northwards along the US and Canadian coast to find a new port to unload its tainted cargo, it was met with the same action, eventually forcing it to

\footnotetext{
5 'International' in this and many North American cases refers to a bi-national union, that is, across the USA and Canada, rather to an international labor organization or trade union secretariat.
} 
cross the Pacific Ocean to Japan. But in Japan, its targeted cargo was outright blockaded. The ship was eventually sold and renamed.

The longshore workers' employers in the Pacific Maritime Association (PMA) pressed hard with legal suits, but not against the ILWU. Rather, the PMA pursued individuals within it, and those union sustaining organizations on the community picket that the PMA had identified by their banners. The core suits focused on an ILWU-IBU (International Longshore and Warehouse Union-Inland Boatmen's Union) member, Robert Irminger, who had captained the picket while off work, and on ILWU Business Agent, Jack Heyman, who had handed out leaflets to the longshore workers to inform them of the picketers' grievances and of their own health and safety provisions.

Heyman's union-backed defense was successfully constructed on the basis of California's anti-Strategic Lawsuits Against Public Participation law, which strongly upheld the Bill of Rights-related protection of free speech, expression, and assembly. A defense based on this legal provision, we note, required that Heyman's (labor) lawyers showed that the specific expressions of his actions, that is, picketing and handbilling, were free speech activities that were protected by state and federal constitutions and well-established by Supreme Court decisions in previous civil rights cases. Following the success of this defense, Heyman then began a lawsuit against the PMA for having attempted to deny him his Constitutional rights to free speech!

Irminger's defense, though based on the same roots, was more complex because, the PMA claimed, Irminger had violated a temporary restraining order. The court generally agreed with the PMA, but ruled that the violation was sufficiently minor and could be settled by Irminger claiming 'no contest' and accepting a one-day suspended sentence. But the PMA - with its eye on obtaining a permanent injunction against the union - smelled blood in the verdict and refused to settle unless Irminger were also to name all the individuals and organizations who had in any way been involved in the picket. But though the case was against individual-citizen, Irminger, the PMA also obtained a court order against the ILWU, demanding that the union produced all documents and records of communications that in any way concerned the blockade.

The union was far from new to the task of defending itself on the basis of constitutional rights to freedom of speech and freedom of conscience; ${ }^{6}$ but an injunction to produce all documents was a challenge that it was not sure it could meet easily. The challenge, however, was met: When the union president, Brian

\footnotetext{
${ }^{6}$ Historical tracing of the ILWU's repertoire shows that, in this labor-decategorizing state of old, the USA, a citizen-based repertoire was in evidence from the years of its foundation. A citizen repertoire was used to protest Mussolini's invasion of Ethiopia and Imperial Japan's invasion of Manchuria in the 1930s; and it deepened with the rise of the innovating American Civil Rights Movement in the 1950s and 1960, and with an impressive array of campaigns against Apartheid and labor repression in Central America in the 1970 s and 1980 s.
} 
McWilliams, fielded his legal department for advice, the union's editor-journalist chanced upon the meeting and was welcomed to contribute to the discussion. Somewhat amused by the gravitas of the discussion, Steve Stallone informed McWilliams and the lawyer that he had taken possession of the relevant documents for the purpose of writing a series of articles on the Neptune Jade for the union's newspaper, The Dispatcher, and that California's Shield Act, which extended federal constitutional guarantees of freedom of the press, accorded him, as a journalist, qualified privilege. The union's lawyer was not familiar with this law, but was certainly happy to investigate it. A few hours later, he returned with a recommendation that the Shield Act form the basis of the union's defense. McWilliams was delighted to approve the strategy and to even have the union 'hat-switch' to a new organizational category: that of publisher. The union subsequently claimed - and the court agreed - that, as a publisher of a registered newspaper, the ILWU had the right to immunity from an order to produce its organizational documents.

In sum, the ILWU innovated around its citizen repertoire and trumped the PMA's attempt to bring the union to heel when, first, its leadership opened itself up to the advise of an insider to the union with a long history of civil activism - in this case for press freedoms. Second, this openness led to an innovation in the ILWU's long-standing citizen repertoire that further explored the citizen rights domain of the USA and the state of California, in the course of which the union discovered for itself another protective category to utilize - that of publisher.

Throughout the year-long Neptune Jade campaign, other, more familiar performances from the citizen repertoire were also utilized: union members and community supporters demonstrated in front of the court houses and employers' officers; they rallied in downtown San Francisco; and prominent citizens, such as former Governor and then Mayor-Elect of Oakland, Jerry Brown addressed the demonstrations and provided a letter to the union defense team declaring that he too had walked the line for Liverpool against the Neptune Jade. Together they all rallied behind the slogan: 'Free Speech is Labor's Right'.

Such community momentum and broad frames, followed by court room successes meant that the union could finally threaten to use workers' ultimate weapon, the full strike, despite the strict bans on striking outside of bargaining periods and even then for strictly contract bargaining purposes. As Irminger's had been the most ominous case during this long campaign and he seriously faced the prospect of imprisonment if the court were to order him to 'name names' something which he had no intention of doing as a matter of principle. But the year-long citizen campaign had now changed the balance of power. The PMA had won little up to this point, and, indeed, had only faced intensified and broader mobilization as more and more social groups joined the Neptune Jade campaign to defend civil liberties and denounce the PMA's 'McCarthyite tactics'. The union leadership thus decided to issue the credible threat of a West Coast port shutdown on the day of Irminger's court hearing if the PMA were not to drop the case. 
Shortly before Irminger's case came to court, the ILWU and the PMA entered serious and direct discussions. Brian McWilliams and the union's Coast Committee made clear that unless the Irminger case was dropped, the whole Neptune Jade affair would create martyrs and engender a bitterness that would haunt the upcoming negotiations and indeed many more to come. Moreover, McWilliams told the PMA that on the day of Irminger's trial, he would shut down the whole West Coast of North America, including Canada, which was a part of the union, and would do so in defense of Irminger and of the Bill of Rights.

Faced with the massive financial pain, organizational mayhem, and public relations disaster that a coast-wide shutdown in defense of citizen rights would ensure, alongside a published legal case that would remind the legal world for generations to come of the PMA's denial of rights to one citizen worker should Heyman's counter-suit against the PMA proceed, the PMA dropped its case against Irminger and other unrelated cases against the union in exchange for Heyman dropping his counter-suit.

The actions in solidarity with Liverpool, and the ensuing campaign to defend those actions were a victory for the union, enabled by a repertoire drawn from the liberal democratic rights domain.

\section{From West to East Coast}

But the famously progressive ILWU (Kimeldorf, 1988; Wellman, 1995) was not the only port union in the USA to support Liverpool. The equally famous conservative union of the East Coast, the International Longshoremen's Association (ILA), also joined the world actions - early, and to produce the most effective of solidarity actions for Liverpool. For our purposes, we note that their actions underscored that the citizen repertoire holds in neo-liberal USA, regardless of ideology.

Invited to tour the East Coast ports by the ILA President in 1996, the Liverpool Dockers, upon arrival in the USA, were informed by their activist escorts that American workers are banned from secondary boycotts, but that they nevertheless have the right as individual citizens to the freedom of conscience not to cross a community picket line. Following their initial shock at the thought of organizing pickets in a country and port where they knew neither the workers nor the police, the Liverpool Dockers put their trust in their new friends and steeled themselves to try. First, they set up three-men pickets in New York, then Baltimore and even further down the coast, as they chased a ship of their employer's largest customer, the ACL, and appealed to the on-duty ILA workers not to cross their picket. The ILA workers refused to cross, again on health and safety grounds, while the union was at hand with civil libertarian lawyers to help the Dockers with their subsequent injunction. Those solidarity actions by a most conservative and top-heavy union produced for Liverpool its most important single result during the first part of their campaign: ACL pulled out of Liverpool and discussions between the 
Dockers' union and employer were more earnestly resumed. Achieved, again, by resort to a citizen repertoire.

To summarize, in responding to the Liverpool lockout, American longshore activists of disparate ideological traditions relied, first, on external allies and, at times, on their own workers-as-citizens rights when off duty, to set up a community picket against Liverpool-associated ships that the on-duty longshoremen could then refuse to cross on grounds of health and safety regulations. Second, where and when sued, they relied on their First Amendment rights as citizens to defend themselves.

\section{Labor rights in Sweden}

Scoring high on Esping-Andersen's measure for social rights, and indeed classified by all major typologies of OECD political economies as a 'Coordinated Market Economy', 7 Sweden is a particularly apt case for comparison because it has been considered the standard bearer, not only of corporatist bargaining arrangements, but of corporatism in a highly internationalized, open trading environment (Katzenstein, 1985; Huber and Stephens, 2001). Further, like the USA, Sweden has two port unions that are organizationally and ideologically disparate.

The Swedish Dockers' Union (SDU) organizes just over half of Sweden's Dockers, but closer to $70 \%$ in the country's largest port, Gothenburg. The Swedish Transport Workers' Union (STWU) organizes the other half and is the owner of the national contract. ${ }^{8}$ Though the two unions are not as far apart ideologically as the two American unions, the STWU and the SDU do nevertheless differ ideologically with respect to social democratic hegemony in Sweden, and in their democratic constitutions and practices. The STWU is affiliated to the Landsorganisationen Sverige (LO) and is associated with the Social Democratic Party. It is therefore part of the strong tradition of social democratic corporatism, and relies on professional, appointed leaderships. The SDU is a breakaway rank-and-file union that was established in 1972, defining itself against corporatist political structures and practices, and by its participatory democratic constitution, featuring direct rank-and-file control of all organizational decisions, and high leadership accountability. While its founding leaders and all subsequent ones at both national and local levels have been an eclectic mix of Communist Party, Centre (Farmers) Party, Social Democratic Party and no-party members, its rebellious emergence from the STWU and its bitter battles with the STWU and the LO for the national contract have fostered an anarchosyndicalist culture in practice (see Gentile (2006) for a brief history of the union).

The Liverpool Dockers had only historically distant connections with Sweden, but with ACL's cross-Atlantic traffic through Liverpool ending in Gothenburg,

\footnotetext{
7 In Pontusson's schema, 'Social Market Economy'.

${ }^{8}$ Swedish labor law permits only one union to sign a contract, and then provides for the extension of that contract to all workers in the industry.
} 
support from the country was as high a priority as was the USA. Their first invitation to Sweden was issued early in the dispute by a group of Trotskyist activists external to the union who had heard of Liverpool through their English party comrades. Once they brought the Liverpool Dockers to Sweden at the end of 1995, the activists contacted left union activist, Bo Johannson, in the port of Gothenburg, and the SDU's then head of its International Affairs, Bjorn Borg, based in Stockholm.

The union was immediately interested in meeting with the Liverpudlians and facilitating visits to rank and file messes in a number of ports. These messes were shared by both STWU and SDU members. The SDU rank and file voted to engage in sympathy actions and its officials sent due notice to the Swedish Harbour Association announcing a 24-hour blockade on all ACL containers to and from Liverpool in all ports, plus 12-hour delays on all ACL vessels arriving at the strategically important Gothenburg.

Such concerted and publicly declared action was not problematic for the Swedes, because the Swedish constitution guarantees the right to association, and Swedish labor law, reaffirmed by labor court decisions, distinguishes between solidarity and political strikes, allowing the former and banning the latter. ${ }^{9}$ A solidarity boycott is defined as one that is of an industrial nature, for example, one that involves workers without a contract or a matter arising out of an official dispute, and the provision extends to international disputes. While controversy over officialness lay at the heart of the Liverpool dispute, Swedish employers did not challenge the SDU's view of the dispute's legitimacy. The boycott extended from the end of 1995 until ACL left Liverpool mid-1996; and it resumed a month later, the moment the now frequent visitors and writers from Liverpool communicated to their new comrades in Gothenburg that ACL had returned.

While the boycott was SDU-led, the STWU's workers also participated, and the STWU leadership, though lukewarm about the Liverpool dispute, did not try to prevent it. In fact, early in the Liverpool campaign, the STWU's leadership visited Liverpool, met with and addressed the dockers, and made financial donations. The STWU leadership did ensure, however, that it visited on an occasion separate from the Liverpool Conferences, so as to avoid participating in an international

\footnotetext{
9 The Swedes were to discover the Social Democratic limits of their solidarity fostering laws during the Campaign against the EU Port Services Directive, early this century. Strike action during this campaign was legally deemed a 'political strike', which is banned in Sweden. Both unions managed a couple of hours of stoppages during one international day of action against the Directive, but largely because their employers were themselves opposed to the Directive and signaled an OK to the STWU and SDU to proceed with limited actions without fear of litigation. When the SDU tried to conduct a second round of strikes some weeks later, however, it found itself, on one hand, in court against the employers, and, on the other, with a STWU (ports) leadership circular, No. 216/2001, to all STWU members, instructing them to do any work refused by striking SDU members if asked to do so by their management. The scabbing did not occur, however, due to the fact that the STWU rank and file knew that such an act would have provoked violence on the docks - certainly the SDU members were prepared to test their competitors' swimming skills (in iced water if necessary) should they have tried to take their work.
} 
event alongside its national competitor. For its part, the STWU rank and file was highly exposed to the SDU's discussions and meetings about Liverpool and with the Liverpudlians, because they shared the same workers' dispatch hall in each port. They joined the blockade without quibbles or qualms.

With regard to external allies, however, none were apparent in the conduct of the actual boycott by either union. Once the contact was made and the decision taken by Sweden's dockers to support Liverpool, the strong pro-solidarity legal environment permitted the workers to withdraw their labor power on their own. To be sure, the SDU organized and hosted many public events over the 2-year campaign: in April 1996, it invited the Liverpudlians as special guest speakers to its National Congress; the core left activists in Gothenburg, led by Bo Johansson, organized a chain of cultural and fundraising events over the next 2 years, including a Gothenburg Gala for Liverpool featuring high profile performers; and the activists arranged the dedication of one of the Maoist KPML(r)'s annual peace races to Liverpool.

But these activities were not instrumentally related to the conduct of the blockade. They served to raise awareness and sympathy among the Swedish Dockers and the various left activists that attended; they were a platform from which to raise money for Liverpool; and indeed, they helped construct strong transnational friendships that have survived the campaign. But unlike the US case, those alliances were not instrumentally integral to the boycott as action. The dockers blockaded the ship as 'workers', utilizing the strong, labor categorizing laws of social democratic corporatist Sweden.

\section{Adapting and failing to adapt repertoires}

Two other cases help us to round out both the empirical and the theoretical picture we have drawn. For whilst the USA and Sweden reflect basically stable frameworks neo-liberal in the first case and corporatist in the second - the post-1980s period has seen significant cases of regime change from a corporatist to neo-liberal regime. In these cases, we should see a shift in labor repertoires - away from a traditional recourse to labor rights and towards the enhanced use of citizen rights - among those union movements and unions that survive regime change. But we also see labor union choices, some of which have adapted better than others to the shift to neo-liberalism. As we will see in this final section, Australian union leaders adapted with alacrity, while Britain's were loathe to adapt their traditional labor rights repertoires to the new conditions of Thatcherite neo-liberalism.

\section{Adapting repertoires in Australia}

As the Liverpool episode was reaching its end, the Australian state was being violently torn from its peculiar corporatist roots to a neo-liberal regime modeled, in many particulars, on that of the USA and post-Thatcher Britain. Where only 
months before the government's first attempt to destroy the MUA, Australia's wharfies ${ }^{10}$ were conducting go-slows and work-to-rule on ships from Liverpool, and paid a tolerable fine when they subsequently defended their actions as employment-related issues at Australia's idiosyncratic labor courts, it could now no longer apply such performances without risking bankruptcy, deregistration, and even criminal charges against its leaders. As a result, we find the port workers of the MUA responding with a broad repertoire of citizen rights-based tactics to a crisis triggered by the government and employers in the late 1990s.

Regime change and the decategorization of labor. The conservative Liberal Party's historic long term in opposition during the 1980s and early 1990s fuelled intra-party contention between the established 'Wet' faction and the growing 'Dry' faction, which introduced allies from non-traditional segments of capital and New Right think tanks. Winning the party room battles and then executive government power in 1996, the Dry faction and the Liberal Party's coalition partner, the corporate farming linked National Party, proceeded to 'out-source' its transport and industrial policy planning to selectively tendered consultants linked to all its new external allies in capital and the New Right. At the same time, it cast out organized labor from the policy making process established by the previous Labor government, namely the Prices and Incomes Accord, through which the union movement had achieved considerable social policy gains for workers in exchange for wage restraint at a time when the Labor Government was internationalizing Australia's heavily protected industrial sector and financial system.

The John Howard-led Liberal Governments' resulting institutional reforms of 1997 included first, a rolling back of the hallmark of antipodean corporatism, the Australian Industrial Relations Commission; ${ }^{11}$ second, an introduction of the 'freedom of choice' not to join a union, thereby targeting powerful unions' closed shop, upon which they had relied for control at the point of production; third, a wholesale transfer of legal bans on secondary boycotts from the purview of the labor courts and to the watch dog of the neo-liberal order, the Australian Competition and Consumer Commission (ACCC); and, fourth, a total banning of primary boycotts in matters affecting international trade, also now under the ACCC. Finally, the government cabinet secretly approved a document based on the recommendations of its preferred consultants to take an 'activist approach' in triggering a dispute with the MUA. That activist approach, however, meant eliciting the general support of interested elements of capital, and the agreement of the stevedoring firms to trigger a dispute. The government found lukewarm support from most of the firms it approached, while one of the two stevedoring companies, P. \& O., refused outright to trigger a dispute of any description, complaining that the governments' new laws were not as watertight as Mrs Thatchers'

10 See footnote 5 .

11 A complex state and federal system of compulsory courts for conciliation and arbitration. 
to warrant the risk. Locally expanding Patrick Stevedores, on the other hand, was interested and keen to start.

Both the Government executive and Patrick fully expected the MUA and the Australian Council of Trade Unions (ACTU) to engage their traditional labor repertoire, including performances such as strikes and sympathy strikes, against any provocation, and to thus fall foul of the new anti-labor Workplace Relations Act. But that is where the neo-liberalizing elites miscalculated, and badly. For the MUA, with the top leadership of the ACTU and state labor councils fully behind it, developed an array of performances based on the category of citizen, on the civil court system, and on the Common Law of Torts, ${ }^{12}$ the Corporations Law, and the contradictions of the government's new law.

Innovation took time at first. During an early series of attacks against the union, the MUA national leader, John Coombs and his team focused on strategies designed to avoid the highly threatening domestic arena, where they had no doubt that the union's traditional repertoire would only invite state repression. So, in September 1997, when one shipping agent announced that an approaching ship would use non-union labor, the MUA elicited the ITF's and the ILWU's threats of an international boycott. This succeeded in keeping the battle offshore and away from Australia's courts and police. Similarly, when John Coombs was leaked secret information about an attempt to send Australian military personnel to Dubai to train as a replacement workforce, he and the ACTU focused on activating the until then ambivalent Labor Party Opposition ${ }^{13}$ to investigate government involvement in the scheme, shame the government in Parliament, and use both the ITF's and the Labor Party's diplomatic connections with the United Arab Emirates to end the scheme before the non-union force was due to return to Australia.

But when, in January 1998, Patrick Stevedores leased a berth at Melbourne's Webb Dock to the National Farmer's Federation to train non-union workers, the threatening domestic arena could no longer be avoided. Repertoirial innovation shifted into top gear: the MUA resisted its instinct to call for direct strike action in favor of a 'Peaceful Assembly' at the Webb Dock gates that included off-duty workers from the MUA and allied unions. Traditional actions were not resisted with ease; but the MUA and ACTU leaderships convinced the MUA membership to apply its famed discipline towards an alternative, from which point other unions could not but respect the MUA's choice and follow suit. Thus unionists in the construction, electrical, nursing, and entertainment industries applied their worker skills to construct quasi-carnival sites in place of the traditional industrial picket. And, as the weeks passed and the

12 This notoriously anti-labor law in the Common Law tradition had been largely by-passed during the 20th century by the characteristic institutions of antipodean corporatism, the Australian Industrial Relations Commission.

13 The Labour Party was in disarray after its thumping electoral loss to the Howard Government. It was itself in the throes of a 'Third Way' shift, which included neo-liberalizing proclivities premised on drawing distance from the union movement. 
pickets were deemed safe, increasing members of the broader citizenry joined the assemblies, making them 'Peaceful Community Assemblies'. But these sites, nevertheless, disrupted Patrick's operation, attracted media attention to the protest, and helped the police privilege their right to maintain the peace over the Government's and Patrick's pressure to enforce law and order. During April's national lockout, Melbourne's successful innovations were quickly diffused to the rest of the country through industrial union structures and media coverage.

Critical to the evolution of the citizen repertoire on the ground was first, the ACTU's and MUA's determination to avoid demonstrations that would increase engagement with the police and hence the chance of violent interactions; ${ }^{14}$ and second, the MUA's strong relationship of trust with ACTU Assistant Secretary, Greg Combet, a former employee of the MUA, and with the head of its unity pact union, the CFMEU's ${ }^{15}$ John Maitland. But third, and most importantly, was the example and inventiveness of the Victorian Trades Hall Council (VTHC) and its unassuming leader, Leigh Hubbard, who had already had the experience of battling Jeff Kennet's neo-liberalizing state government of Victoria. For, following that state's demolition of labor categorizing laws and institutions in the early 1990s, the VTHC had embarked on a policy of building strong ties with social welfare centers, immigrant communities, small farming communities, and the churches, as well as engaging in concerted bridge building across the ideological chasm that was the Victorian labor movement.

Innovation in the legal arena, however, was slower to develop, in part because of the speed and concentration of events on the ground, and in part because the legal arena had not been one that had needed much thought and inventiveness during the classical era of Antipodean Corporatism, during which the highly institutionalized labor tribunals framed tactics. It was not until a brazen, infuriated, and dedicated Melbourne labor lawyer, Josh Bornstein, called Combet at the height of the Webb Dock non-union training scheme that a new path was forged. A young lawyer ensconced in Melbourne's Jewish legal fraternity, with its long and venerable tradition of civil and labor rights activism, Bornstein pointed to some critical contradictions in the new workplace laws that concerned the right to association. Coombs and Combet, realizing the lacuna among their arenas of activity to date, decided to place their trust in Bornstein and let him formulate a legal strategy, providing it could accommodate the 'peaceful community assemblies'. Bornstein's legal team, in turn, started planning a case of illegal conspiracy against Patrick and the farmers, and against the government itself, and later

\footnotetext{
14 This was the result of a lesson hard learned: just prior to the Howard Government's first Budget, the ACTU had organized a mass demonstration outside Parliament House to protest the pending industrial relations reforms as well as proposed welfare cuts. Violence erupted at one corner of the demonstration under heavy police guard. The incident ended as a public relations disaster for the ACTU and a political coup for the government, which had repeatedly labeled unionists as thugs.

15 The Construction, Forestry, Mining, and Energy Union.
} 
assumed the services of a Queen's Counsel experienced in the Common Law of Torts and the Corporations Law, and with intimate knowledge of the court's extraordinary powers. To the extent that Bornstein's team utilized the now comparatively emasculated industrial courts, it was largely to gather information - by means of subpoenas to the MUA's enemies - for the larger conspiracy case the MUA would file for in the Federal Court. ${ }^{16}$

The dispute escalated in April 1998 when, in the dead of night, Patrick-employed security firms raided all the country's ports by land and sea and locked out all Patrick employees. The Minister for Workplace Relations, Peter Reith, immediately emerged from a late meeting in Parliament House to congratulate Patrick and announced a redundancy package to seal the mass sackings. The MUA, in turn, moved to nationalize and broaden the peaceful community assemblies; and its union allies in the VTHC and other regional councils trained the growing numbers in non-violent resistance and engaged civil rights lawyers to inform participants of their rights in the event of arrest. But critically, following the example of CFMEU leader John Maitland, rostered union leaders organizing the pickets - following their receipt of injunctions - 'hat-switched' from the category of organized labor to return to the pickets as 'citizens on a family day out'.

Unionists' civil disobedience attracted more citizens to the Assemblies by the day and the process reached critical mass when Patricks obtained an injunction from the Supreme Court of Victoria against any and all persons present at the port gates. This 'Ban the World Injunction' was immediately defied by the ACTU's Executive, behind which rallied journalists, civil libertarians, and a host of affronted citizens, and it was successfully challenged in an appeal by the union, former premiers, Opposition parliamentarians who represented the port area, and prominent Australians.

In the meantime, the union and its lawyers were also using the highest courts of the civil system. During that highly contentious month of April, they secured a ruling from the Federal Court of Australia that the union had 'an arguable case of illegal conspiracy' against its employer, the farmers, and the government to dismiss workers for exercising their right to join an association (a union) of their choice. For, first, the lawyers had argued, while Minister Reith's new law introduced a right not to join an association of choice, there was nevertheless a right to join an association of choice. Second, utilizing the traditionally anti-union Common Law of Torts, the lawyers argued that Patrick, the National Farmers Federation, and the Government executive had conspired to break the new law, while Patrick also abused the Commercial Law through a complex and secret company restructuring designed to make the illegal dismissals irreversible. In practical essentials, the High Court of Australia then upheld the Federal Court's ruling.

But while most accounts of the dispute end with this victory and the wharfies' march through the ports' gates, the MUA still had its most ominous battle before

\footnotetext{
${ }^{16}$ For an intricate tracing of the evolution of the repertoire and the expansion into new legal arenas, see Gentile (2002, 2009).
} 
it: that with the semi-autonomous ACCC, whose brief it was to uphold and legally enforce the neo-classical economic principle of competition between companies for the benefit of a 'free market' and consumers, and now, in effect, even competition between workers. This newly empowered institution was suing the MUA leadership for damages, including those incurred through a US West Coast solidarity blockade of non-union loaded cargo from Melbourne.

Unbeknown to the MUA, the ACCC had been monitoring the MUA's activities since a mere month after the Federal Cabinet secretly approved its 'interventionist strategy' - some nine months before the national lock out - and needed only to show that the union leadership had in any way authorized or condoned the American longshore workers' blockade during the union leaderships' cross-Pacific phone conversations (which the ACCC had traced) for the union's courtroom victories to have proven pyrric victories. Significantly, demonstrating the power of the neo-liberal state in coercing labor and in maintaining that anti-labor order, this body sought to chill international solidarity by suing Australian unionists and ITF Flags of Convenience Inspectors as 'Australian citizens' allegedly conspiring to break Australian boycott laws. In short, the ACCC was disciplining pro-worker citizens in the interests of pro-capital and pro-consumer citizens.

Where American unionists have long relied on the strongly institutionalized Bill of Rights to counter such anti-labor coercion, the union movement in constitutionally weaker Australia now found itself at the limits of its own citizen rights domain - at least, institutionally. For politically, their courtroom victories and the burgeoning community assemblies threatened the government with a full conspiracy trial during the following year's election; while, with respect to Patrick, the worksite and courtroom contention had overdrawn the company's finances beyond the point that its bankers would tolerate. Pressure on the ACCC was brought to bear and it settled with the MUA. The MUA lived on, and the Australian union movement, though now devoid of the political and institutional power resources through which it had helped deliver Australians their former social rights, now at least had proof of the power of the liberal domain of citizen rights. ${ }^{17}$

\section{Failing to adapt in Britain}

Not so the Liverpool Dockers, or rather their union, the TGWU, and the British labor movement in the decade following Thatcher's neo-liberal assault on the Britain's post-war Keynesian social state. Having totally decategorized organized

\footnotetext{
17 The Australian union movement has since involved itself in the campaign for an Australian Bill of Rights to strengthen citizen rights, at the same time as it has supported its familial party, the Australian Labor Party, in subsequent election campaigns in the hope of reversing its loss of legal rights and political influence. This last and more traditional effort focused on campaigning in the media and community during the 2007 election campaign against further Howard government industrial relations 'reforms'. By so doing, the ACTU helped achieve a change of government, after which it focused on regaining some of its pre-Howard era categorical power as labor.
} 
labor from the polity, both politically and institutionally, Thatcher's neo-liberal revolution had delivered workers as individuals to their employers. But the British union movement's response did little to change or subvert this. It failed to adapt its repertoire in response to the Thatcher government's attack on the National Union of Miners, while, in 1989, the TGWU leadership responded to the abolition of the National Docks Labor Scheme with a cautious legalistic approach that meandered through the myriad of anti-labor laws on those same laws' terrain (see Turnbull et al., 1992). This contributed to the loss of a national wave of dock protests, sealed by the union's deregistration in all ports, bar two - one of which was Liverpool.

The MDHC's mass dismissal of the Liverpool Dockers in 1995 presented the TGWU and the British union movement with yet another occasion to seek new, polity-appropriate weapons of labor as well as, no less, a highly experienced and motivated group of workers and local community to focus its comeback on. Again a polity-redundant option was preferred. Under Thatcher heir, Prime Minister John Major, some union leaders were now entertaining the possibility of 'social partnership' as a mode of industrial exchange, while many others were pinning their hopes to a change of government so as to ensure it. Largely inspired by Germany's 'social partnership' model and the term's growing hegemony in European Union circles and the mainstream industrial relations literature, there was nevertheless neither the institutional foundation for 'social dialogue' between the 'social partners' in Britain, nor the incentive to develop them. For with laws that had served employees to their employers on a platter - one by one - capital had no incentive to dialogue with unions, much less view them as 'partners'. Some elements of the British union movement, however, were interested and wanted to prove their reliability as a social partner by showing its restraint.

The TGWU refused to declare the Liverpool dispute official, fearing that this would put it at risk of the sequestration of its funds, and, as the campaign drew on, threaten a 'New Labor' victory. Under Bill Morris, the TGWU and its Executive refused to call for the support of the ITF or to field widely for advice on legal and tactical challenges, preferring instead to simply focus on a negotiated settlement with redundancy packages. There were, however, alternatives to such closure to innovation: while the TGWU had undergone a series of internal changes since its heyday under the legendary Liverpudlian, Jack Jones, its creatively militant tradition and cadres had not been defeated. And while Morris himself had little experience with ports, there were many at Transport House ${ }^{18}$ who did. Inside the TGWU were senior officers with intimate knowledge of the Liverpool region and strong ties of trust with the Liverpool Dockers; and some were also highly informed about the MDHC, and its expanding and vulnerable business interests and networks. But the new leadership denied these officers

18 The TGWU's headquarters in London. 
postings in the region or in the union's docks section. When they tried to approach Morris with suggestions, they were barked back into their non-Liverpool posts and non-port affairs. The point to underscore here is that it was not the union leadership's ideological position that determined this closure - Morris, indeed, had been elected as the union's Left candidate - but rather the problem lay in his and the executive's refusal to seek and listen to alternative views and plans, and a determination to pull rank on those that tried to offer them.

The TGWU leadership closed itself up to an inner circle and to the advice of inhouse lawyers. Liverpool, its workers and families, and their inventive community supporters, such as 'Reclaim the Streets', were seen, not as an opportunity for national union revival, but rather as a nest of militant trouble makers. Ironically, Transport House also hosted the long-retired Jack Jones in an honorary office. The elderly Jones sat there during the long dispute, heart-broken and concerned that victories are denied to leaders who do not build trust with the membership and who do not see the membership and its communities as a resource.

Ironically, according to the Liverpool Dockers' post-dispute submission to the ILO, the TGWU leadership had in fact neglected to officially repudiate the dispute in the technically required manner, thereby leaving the dispute (at least arguably) official and itself open to the very litigation it had sought to avoid when it distanced itself from the Dockers' demands for reinstatement. We do not have sufficient evidence to indicate whether the failure to formally repudiate the dispute was an oversight or not; however, as the union was clearly not supporting the Dockers' demands for reinstatement, preferring instead to provide financial relief and negotiate a redundancy package, the employers did not turn on the union.

The Liverpool Dockers did not simply appeal to its national leadership or wait for it to change its tack. They set off to build the largest transnational docker network and achieved the most widespread international days of action in docker history. Their networking also found powerful brokers among the national affiliates of the ITF, who in turn pressured and at times shamed Morris and the ITF secretariat. The pressure bore fruit when some TGWU insiders - unbeknown to Morris - secured a resolution in a union committee that was broad enough to hand to the ITF's General Secretary, David Cockroft as an official call for action, resulting in a historic international day of action in January 1997. The ambush, however, was not sufficient to unlock the union leadership beyond that day Morris re-took control of the union and did not permit ITF imprimatur for a follow-up international day of action in September, much less an alternative domestic strategy.

By late 1997, the Liverpool Dockers and their families were exhausted. Their historic two and a half years of struggle had taken a heavy toll. Most of them faced crippling debts, some had lost their homes, and the emotional and material strain had even taken five lives. The MDHC made its 'Final final' offer to the union, and Morris imposed a secret ballot on the Dockers. In January 1998, the Liverpool Dockers voted to accept a settlement based on redundancies and permission to form their own 
labor supply company. The dispute was over, and lost. Lost on domestic not international turf, because the union leadership had failed to build trust with its membership, on one hand, and, on the other, it had refused to open itself up to alternatives to its traditional labor repertoire beyond a defensive and defeatist legalism.

Lost above all during the Liverpool Campaign was a prize opportunity to spearhead a reversal to British labor's decade and a half of pounding losses. For here was, in the words of one TGWU insider, 'every union leader's dream': a highly motivated, creative, and militant workforce with the full support of its community. Significantly, the mobilization of the city of Liverpool by the Dockers and Women of the Waterfront had included performances from the citizen repertoire - demonstrations, consumer boycotts, rallies, community-supported pickets, church alliances across the religious divide, and some daring alliances with civil activists. And their picketing tactics were also in constant evolution: to disrupt the miles of dockland and avoid arrest, they organized surprise pickets at different gates and times each day, while the Women of the Waterfront often applied their gender power to disrupt the port's entry, for example, by stuffing their clothing to simulate pregnancy and then challenge the police to 'man handle them if they dared'. But that repertoire was never nationalized by the TGWU across the port and related industries, or across those communities where the union had lost members but still had social networks to build back from.

Similarly, whilst the Liverpool Dockers had fielded legal experts who produced challenging papers for submission to the ILO, their national union did not take these up or inject that initiative into exploring non-labor-related British laws. Instead, the TGWU and the Trades Union Congress pinned their hopes on the incoming Labor Government of Tony Blair and his union-diminishing Third Way to electoral victory.

\section{Summary and conclusions}

Drawing on evidence from the responses of OECD port unions in neo-liberal and corporatist regimes to the Liverpool Dockers' Campaign for reinstatement, and on the Australian union movement's response to regime change to a neo-liberal, we have argued that:

- The structures of labor rights and citizen rights in a given capitalist political economy shape labor's repertoires of action in responding to threats of globalization, even in this most globalized of industries;

- In neo-liberal regimes, such as the USA, where labor's political and institutional categorization is weak, labor is thrown back to the citizen rights that it shares with other groups of citizens to enable its actions of resistance and solidarity;

- In corporatist regimes such as Sweden, where labor's political and institutional categorization is strong, labor has little need to retreat to its citizen rights or to 
alliances with non-labor groups but uses established labor rights and alliances with other workers to enable its actions of resistance and solidarity;

- Those union movements that survive the transition from a corporatist to a neoliberal regime will do so by adapting their strategies to the citizen rights domain; those that fail to shift to a citizen repertoire will fail and weaken.

- Successful innovation within an established repertoire in a stable environment, and successful innovation of the entire repertoire in cases of regime change from a corporatist to a neo-liberal regime are contingent on networks of trust between the union's leadership and the membership, and, most crucially, upon union leaders' openness to outsiders and externally-connected insiders experienced with non-labor contention.

- In the course of regime change from a corporatist capitalist regime to a neo-liberal capitalist regime, while social democracy as represented by labor's categorical inclusion in the capitalist polity is diminished, liberal democracy remains largely intact to assist workers in struggle. ${ }^{19}$

So where did the 'Race to the Bottom' thesis, as specified by Tilly in 1995 err? Certainly not in suggesting that globalization - especially in its neo-liberal avatar - threatens labor's rights. That is clearly the case. But domestic history, domestic institutions, and domestically rooted popular contention - including that which strategically utilizes the international arena - still determines the course of labor struggles. Tilly missed the critical variety of capitalist regimes, largely because his thesis over-determined state dissolution and government powerlessness. In the process, he failed to disaggregate the various domains of rights won in historical episodes of popular contention, and it failed to accord organized labor the strategic ability to shift between the domains that threaten it and the domains that provide it with opportunity.

Regime change from a corporatist to a neo-liberal regime, as in Britain and Australia, did not simply involve de-institutionalization and deregulation, nor did it leave a policy vacuum; rather the process also involved a re-regulation towards new labor-coercive institutions that diminished the categorical power of workers, leaving largely their category of citizen and its sustaining legal and political institutions their major recourse. Moreover, neo-liberal globalization passed through governments rather than over them. The process of state transformation was critically dependent on changing polity alliances within and across executive achieving parties in party-government systems. Both Margaret Thatcher's Conservative Party and John Howard's Liberal Party would have been unrecognizable

\footnotetext{
19 Though beyond the purposes and possibilities of this paper, we also note that in fact the functioning realm of citizen rights in the neo-liberal state is the one realm that distinguishes the neo-liberal state from authoritarian regimes, where both labor and citizen rights are curtailed. Moreover, during periods of war, when neo-liberal governments roll back citizen rights, labor loses its main prop and hence curtails its militancy until such time as a concerted citizen protection and anti-war movement is in full mobilization (see Gentile, 2002, 2009).
} 
to their party antecedents. Once intra-party contention transformed those parties, their respective electoral victories sealed the process of regime change to neoliberalism. For those parties' leaders to then claim, 'There is no alternative' was more than self-serving. But nor did labor contention necessarily prove them right.

Three major implications can be inferred from our findings, regarding social movement theory, transnational mobilization, and globalization.

\section{Social movement theory}

Our work has emerged from within the broad political process approach to contentious politics that Tilly himself did much to found. That approach departed from previous collective behavior and socio-economic approaches to focus on the impact of variables such as political opportunities and threats, resources and ways of framing contention. It was originally specified at the domestic level and therefore has come in for criticism from scholars who believe that globalization erases once-important differences in domestic structures.

These criticisms are well taken but while it is true that the political process approach grew up within national precincts prior to the current age of globalization, we think it has served us well in understanding the variations in unions' reactions to the same transnational episode of contention: precisely because domestic structures matter - and vary - American, Swedish, Australian, and British port workers responded to neo-liberal threats with visibly different combinations of performances from the broad repertoire of contention. We think that efforts to respecify the political process approach at the transnational level - as has recently been done by international relations scholars like Kathryn Sikkink (2005) and sociologists like Tamara Kay (2005) will bear more fruit than an approach which sees globalization as the master process driving all ships in the same direction.

\section{Transnational mobilization}

Much of this work has focused on networks and organizations created explicitly for transnational mobilization, such as the World Social Forum, the European Social Forum and the Chiapas solidarity network. These instances of transnational mobilization are important and the research they have inspired is beginning to break down the walls among social movements and social movement researchers on various continents. But in focusing so heavily on dedicated transnational organizations, they elide an important sector of transnational cooperation and mobilization: the solidarity of organizations created for domestic struggles which respond to international threats through domestically-focused campaigns. Our work has centered on a union movement - port workers - who are particularly imposed upon by globalization. Would our findings apply as well to other sectors? That question is beyond the scope of this paper, but we think that more domestically rooted unions would, if anything, be more conditioned by domestic rights regimes than the one we have studied. 


\section{Globalization and transnational collective action}

For rather than being dissolved by globalization, we have seen such activists and organizations activating a number of mechanisms and processes in domestic politics, mechanisms such as the internalization of international conflicts, the shift in scale from the transnational to domestic arenas, and the framing of domestic class conflicts in transnational terms. And when they do so, they have to respond to the peculiar combinations of labor rights and citizen rights in their respective countries. Globalization is surely threatening labor's rights, as Tilly correctly foresaw; but labor will only fail if it does not seize the combinations of political opportunities and dominant rights domain available to it in its national polity, as Tilly would certainly have agreed.

\section{Acknowledgements}

The empirical work and most of the theory in this paper are the responsibility of the first author. We acknowledge the support of the Johns Hopkins University, The Australian Federation of University Women, the Mannheim Center for European Social Research, the Hans Boeckler Stiftung, Sydney University, and Prof. Margaret Levi. We also thank the unions, politicians, government organizations, and individuals who generously provided access to their files. We gratefully acknowledge early critiques by Giovanni Arrighi, Richard S. Katz, and Siba Grovogui. For constructive comments on an earlier draft of this paper, the authors thank Peter Turnbull, Lowell Turner, the EPSR editors, and three anonymous reviewers. We dedicate this article to the late Charles Tilly, who never failed to inspire us, teach us, and push us to correct his arguments.

\section{References}

Arrighi, G. and B. Silver (1999), Chaos and Governance in the Modern World System, Minneapolis: University of Minnesota Press.

Baccaro, L. (2002), 'The construction of “democratic” corporatism in Italy', Politics and Society 30(2): 327-357.

Balme, R., D. Chabenet and V. Wright (eds) (2001), L'Action Collective en Europe, Paris: Presses de la Fondation Nationale des Sciences Politiques.

Caporaso, J. and S. Tarrow (2009), 'Polanyi in Brussels', International Organization (in press).

Castles, F. (1993), Families of Nations: Patterns of Public Policy in Western Democracies, Avebury: Aldershot.

- (2004), The Future of the Welfare State: Crisis Myths and Crisis Realities, Oxford: Oxford University Press.

Cleary, M.R. (2006), 'Explaining the Left's Resurgence', Journal of Democracy 17(4): 35-49.

Compa, L. (2001), 'NAFTA's side agreement and international labor solidarity', Antipode 33: 451-467.

Crouch, C. and W. Streeck (1997), Political Economy of Modern Capitalism: Mapping Convergence and Diversity, London; Thousand Oaks, CA: Sage.

- (eds) (2006), The Diversity of Democracy: Corporatism, Social Order and Political Conflict, Cheltenham, UK: Edward Elgar. 
Della Porta, D. (ed.) (2007), The Global Justice Movement. Cross-National and Transnational Perspectives, Boulder, CO: Paradigm.

Dombois, R. and H. Heseler (2000), Seaports in the Context of Globalization and Privatization, Bremen, Germany: Universität.

Dreiling, M.C. (2001), Solidarity and Contention: The Politics of Security and Sustainability in the NAFTA Conflict, New York; London: Garland.

Dreiling, M. and I. Robinson (1998), 'Union responses to NAFTA in the US and Canada: explaining intra- and international variation', Mobilization: An International Journal 3(2): 163-184.

Erne, R. (2008), European Unions: Labor's Quest for a Transnational Democracy, Ithaca; London: ILR/Cornell University Press.

Esping-Andersen, G. (1996), Welfare States in Transition: National Adaptations in Global Economies, London: Sage.

- (1999), Social Foundations of Postindustrial Economies, Oxford: Oxford University Press.

Ferner, A. and R. Hyman (eds) (1998), Changing Industrial Relations in Europe, Oxford: Blackwell.

Frege, C. and J. Kelly (2004), Varieties of Unionism: Strategies for Union Revitalization in a Globalizing Economy, Oxford: Oxford University Press.

Gentile, A. (2002), 'Docker resistance in the 1990s: transnational and domestic alliance activism under conditions of globalization'. Paper presented at American Political Science Association Annual Convention, Boston.

- (2006), 'Democratic and social movement oriented? Not in corporatist Europe'. Paper presented at Union Democracy Conference, University of Washington, Seattle.

- (2009), Historical varieties of labor contention and hegemony in transnational docker campaigns. Unpublished PhD Dissertation, The Johns Hopkins University, Baltimore.

Hadden, J. and S. Tarrow (2007), 'Spillover or spillout: the global justice movement in the United States after 9/11', Mobilization 12: 359-376.

Hall, P.A. and D.W. Soskice (2001), Varieties of Capitalism: The Institutional Foundations of Comparative Advantage, Oxford: Oxford University Press.

Huber, E. and J.D. Stephens (2001), Development and Crisis of the Welfare State: Parties and Policies in Global Markets, Chicago: The University of Chicago Press.

Johnston, P. (1994), Success While Others Fail: Social Movement Unionism and the Public Workplace, Ithaca, NY: ILR Press.

Katzenstein, P.J. (1985), Small States in World Markets: Industrial Policy in Europe, Ithaca, NY: Cornell University Press.

Kay, T. (2005), 'Labor transnationalism and global governance: the impact of NAFTA on transnational labor relations in North America', American Journal of Sociology 111(3): 715-756.

Kimeldorf, H. (1988), Reds or Rackets? The Making of Radical and Conservative Unions on the Waterfront, Berkeley: University of California Press.

Lagneau, P. and E. Lefébure (2001), 'Media construction in the dynamics of Europrotest', in D. Imig and S. Tarrow (eds), Contentious Europeans: Protest and Politics in an Emerging Polity, Boulder, CO: Rowman and Littlefield, pp. 187-204.

Marshall, T.H. (1950), Citizenship and Class, and Other Essays, London: Cambridge University Press.

Milkman, R. and K. Voss (2004), Rebuilding Labor: Organizing and Organizers in the New Union Movement, Ithaca, NY: Cornell University Press.

Moody, K. (1997), 'Towards an international social-movement unionism', New Left Review 225: 52-72.

- (1998), Workers in a Lean World: Unions in the International Economy, London: Verso.

Murillo, M.V. and A. Schrank (2005), 'With a little help from my friends: partisan politics, transnational alliances, and labor rights in Latin America', Comparative Political Studies 38(8): 971-999.

Parks, L. (2008), In the corridors and in the streets: A comparative study of the impacts of social movement campaigns in the EU. Unpublished PhD dissertation, European University Institute Department of Political and Social Sciences.

Pizzorno, A. (1978), 'Political exchange and collective identity in industrial conflict', in C. Crouch and A. Pizzorno (eds), The Resurgence of Class Conflict in Western Europe since 1968: Comparative Analyses, London: Macmillan, pp. 277-298. 
Pontusson, J. (2005), Varieties and Commonalities of Capitalism, Basingstoke: Palgrave Macmillan.

Regalia, I. (2003), 'Decentralizing employment protection in Europe: territorial pacts and beyond', in J. Zeitlin and D.M. Trubek (eds), Governing Work and Welfare in a New Economy, Oxford: Oxford University Press, pp. 158-187.

Regalia, I. and M. Regini (1997), 'Employers, unions and the state: the resurgence of concertation in Italy', in M. Bull and M. Rhodes (eds), Crisis and Transition in Italian Politics, London: Frank Cass, pp. 210-230.

Regini, M. (2000), 'Between deregulation and social pacts: the responses of European economies to globalization', Politics and Society 28(1): 5-33.

- (2003), 'Tripartite concertation and varieties of capitalism', European Journal of Industrial Relations 9: 251-263.

Rhodes, M. (2001), 'The political economy of social pacts: "competitive corporatism" and European welfare reform', in P. Pierson (ed.), The New Politics of the Welfare State, Oxford: Oxford University Press, pp. 165-194.

- (2003), 'National "pacts" and EU governance in social policy', in J. Zeitlin and D.M. Trubek (eds), Governing Work and Welfare in a New Economy, Oxford: Oxford University Press, pp. 129-157.

Rokkan, S. (1970), Citizens, Elections, Parties. Approaches to the Comparative Study of the Processes of Development, Oslo: Universiteetsforlaget.

Seidman, G. (1994), Manufacturing Militance: Workers' Movements in Brazil and South Africa, 1970-1985, Berkeley; London: University of California Press.

Shorter, E. and C. Tilly (1974), Strikes in France, 1830-1968, New York; Cambridge: Cambridge University Press.

Sikkink, K. (2005), 'Patterns of dynamic multilevel governance and the insider-outsider coalition', in D. della Porta and S. Tarrow (eds), Transnational Protest and Global Activism, Lanham, MD: Rowman and Littlefield, pp. 151-174.

Silver, B. (2003), Forces of Labor: Workers' Movements and Globalization since 1870, Cambridge: Cambridge University Press.

Tarrow, S. (2005), The New Transnational Activism, New York; Cambridge: Cambridge University Press. Tartakowsky, D. (2005), La part du rêve. Histoire du 1er Mai en France, Paris: Hachette.

Tilly, C. (1978), From mobilization to revolution, Reading, MA: Addison-Wesley Pub. Co.

— (1986), The Contentious French, Cambridge, MA: Harvard University Press.

- (1990), Coercion, Capital and European States, Oxford: Blackwell.

- (1995a), Contentious Politics in Great Britain, 1758-1834, Cambridge, MA: Harvard University Press.

- (1995b), 'Globalization threatens labor's rights', International Labor and Working-Class History 47: 1-23.

- (2006), Regimes and Repertoires, Chicago: University of Chicago Press.

- (2008), Contentious Performances, New York; Cambridge: Cambridge University Press.

Tilly, C. and C. Tilly (1998), Work Under Capitalism, Boulder, CO: Westview Press.

Traxler, F. (1995), Farewell to Labor Market Associations? Organized Versus disorganized Decentralization as a Map for Industrial Relations, Avebury: Aldershot.

Turnbull, P., C. Wolfson and L. Kelly (1992), Dock Strike: Conflict and Restructuring in Britain's Ports, Avebury: Aldershot.

Turner, L., H.C. Katz and R.W. Hurd (2001), Rekindling the Movement: Labor's Quest for Relevance in the Twenty-First Century, Ithaca, NY: ILR Press.

Waterman, P. (1998), Globalization, Social Movements and the New Internationalisms, London: Mansell.

Wellman, D. (1995), The Union makes Us Strong: Radical Unionism on the San Francisco Waterfront, Cambridge: Cambridge University Press. 